\section{Central American Bank for Economic Integration (CABEI)}

Established in 1960, the Bank is the financial institution created by the Central American Economic Integration Treaty and aims to implement the economic integration and balanced economic growth of the member states.

Members. (Regional) Costa Rica, El Salvador, Guatemala, Honduras, Nicaragua. (Non-regional) Argentina, Colombia, Dominican Republic, Mexico, Panama, Spain, Taiwan.

Official languages: Spanish, English.

Headquarters: Apartado Postal 772, Tegucigalpa, DC, Honduras.

Website: http://www.bcie.org

President: Nick Rischbieth (Honduras).

\section{Central American Common Market (CACM)}

In Dec. 1960 El Salvador, Guatemala, Honduras and Nicaragua concluded the General Treaty on Central American Economic Integration under the auspices of the Organization of Central American States (ODECA) in Managua. Long-standing political and social conflicts in the area have repeatedly dogged efforts to establish integration towards the establishment of a common market.

Members. Costa Rica, El Salvador, Guatemala, Honduras and Nicaragua.

A protocol to the 1960 General Treaty signed by all five members and Panama in Oct. 1993 reaffirmed an eventual commitment to full economic integration with a common external tariff of $20 \%$ to be introduced only voluntarily and gradually.

A Treaty on Democratic Security in Central America was signed by all five members plus Panama at San Pedro Sula, Honduras in Dec. 1995, with a view to achieving a proper 'balance of forces' in the region, intensifying the fight against trafficking of drugs and arms, and reintegrating refugees and displaced persons.

In addition, the CACM countries signed a new framework co-operation agreement with the EC in Feb. 1993, revising the previous (1985) failing agreement between them, to provide support to CACM's integration plans.

Headquarters: 4a Avenida 10-25, Zona 14, Ciudad de

Guatemala, Guatemala.

Secretary-General: Alfonso Pimentel Rodríguez (Guatemala).

\section{Eastern Caribbean Central Bank (ECCB)}

The Eastern Caribbean Central Bank was established in 1983, replacing the East Caribbean Currency Authority (ECCA). Its purpose is to regulate the availability of money and credit; to promote and maintain monetary stability; to promote credit and exchange conditions and a sound financial structure conducive to the balanced growth and development of the economies of the territories of the participating Governments; and to actively promote, through means consistent with its other objectives, the economic development of the territories of the participating Governments.
Members. Anguilla, Antigua and Barbuda, Dominica, Grenada, Montserrat, St Kitts and Nevis, St Lucia, St Vincent and the Grenadines.

Official language: English.

Headquarters: PO Box 89, Bird Rock, Basseterre, St Kitts and Nevis.

Website: http://www.eccb-centralbank.org

Email: info@eccb-centralbank.org

Governor: Sir Dwight Venner (St Vincent and the Grenadines).

\section{Inter-American Development Bank (IDB)}

The IDB, the oldest and largest regional multilateral development institution, was established in 1959 to help accelerate economic and social development in Latin America and the Caribbean. The Bank's original membership included 19 Latin American and Caribbean countries and the USA. Today, membership totals 48 nations, including non-regional members.

Members. Argentina, Austria, Bahamas, Barbados, Belgium, Belize, Bolivia, Brazil, Canada, Chile, China, Colombia, Costa Rica, Croatia, Denmark, Dominican Republic, Ecuador, El Salvador, Finland, France, Germany, Guatemala, Guyana, Haiti, Honduras, Israel, Italy, Jamaica, Japan, South Korea, Mexico, the Netherlands, Nicaragua, Norway, Panama, Paraguay, Peru, Portugal, Slovenia, Spain, Suriname, Sweden, Switzerland, Trinidad and Tobago, UK, USA, Uruguay, Venezuela.

The Bank's total lending up to 2007 has been US\$156bn. for projects with a total cost of over US\$353bn. Its lending has increased dramatically from the US $\$ 294 \mathrm{~m}$. approved in 1961 to US\$8,970m. in 2007.

Current lending priorities include poverty reduction and social equity, modernization and integration, and the environment. The Bank has a Fund for Special Operations for lending on concessional terms for projects in countries classified as economically less developed. An additional facility, the Multilateral Investment Fund (MIF), was created in 1992 to help promote and accelerate investment reforms and private-sector development throughout the region.

The Board of Governors is the Bank's highest authority. Governors are usually Ministers of Finance, Presidents of Central Banks or officers of comparable rank. The IDB has country offices in each of its borrowing countries, and in Paris and Tokyo.

Official languages: English, French, Portuguese, Spanish.

Headquarters: 1300 New York Avenue, NW, Washington, D.C., 20577, USA.

Website: http://www.iadb.org

President: Luis Alberto Moreno (Colombia).

\section{Latin American Economic System (SELA)}

Established in 1975 by the Panama Convention, SELA (Sistema Económico Latinoamericano) promotes co-ordination on economic issues and social development among the countries of Latin America and the Caribbean.

Members. Argentina, Bahamas, Barbados, Belize, Bolivia, Brazil, Chile, Colombia, Costa Rica, Cuba, Dominican Republic, Ecuador, Grenada, Guatemala, Guyana, Haiti, Honduras, Jamaica, Mexico, Nicaragua, Panama, Paraguay, Peru, Suriname, Trinidad and Tobago, Uruguay, Venezuela. 